\title{
Melanocortin-4 Receptor Gene Mutations in Obese Slovak Children
}

\author{
D. STANIKOVA ${ }^{1,2}$, M. SUROVA ${ }^{1}$, L. TICHA ${ }^{2}$, M. PETRASOVA ${ }^{3}$, D. VIRGOVA $^{4}$, \\ M. HUCKOVA ${ }^{1}$, M. SKOPKOVA ${ }^{1}$, D. LOBOTKOVA ${ }^{2}$, L. VALENTINOVA ${ }^{1}$, M. MOKAN $^{5}$, \\ J. STANIK ${ }^{1,2}$, I. KLIMES ${ }^{1}$, D. GASPERIKOVA ${ }^{1}$
}

${ }^{1}$ DIABGENE Laboratory, Institute of Experimental Endocrinology, Slovak Academy of Sciences, Bratislava, Slovakia, ${ }^{2}$ First Department of Pediatrics, Medical Faculty of Comenius University, Bratislava, Slovakia, ${ }^{3}$ Department of Pediatrics, Medical Faculty of Safarik University, Kosice, Slovakia, ${ }^{4}$ Pediatric Department of Hospital in Levice, Levice, Slovakia, ${ }^{5}$ Department of Internal Medicine, Jessenius Medical Faculty of Comenius University, Martin, Slovakia

Received November 24, 2014

Accepted March 27, 2015

On-line June 5, 2015

\section{Summary}

The most common etiology of non-syndromic monogenic obesity are mutations in gene for the Melanocortin-4 receptor (MC485) with variable prevalence in different countries $(1.2-6.3 \%$ of obese children). The aim of our study was 1) to search for MC4R mutations in obese children in Slovakia and compare their prevalence with other European countries, and 2) to describe the phenotype of the mutation carriers. DNA analysis by direct Sanger sequencing of the coding exons and intron/exon boundaries of the MC4R gene was performed in 268 unrelated Slovak children and adolescents with body mass index above the $97^{\text {th }}$ percentile for age and sex and obesity onset up to 11 years (mean $4.3 \pm 2.8$ years). Two different previously described heterozygous loss of function MC4R variants (i.e. p.Ser19Alafs*34, p.Ser127Leu) were identified in two obese probands, and one obese (p.Ser19Alafs*34), and one lean (p.Ser127Leu) adult family relatives. No loss of function variants were found in lean controls. The prevalence of loss-of-function MC4R variants in obese Slovak children was $0.7 \%$, what is one of the lowest frequencies in Europe.

\section{Key words}

Monogenic obesity • Epidemiology • Children • MC4R

\section{Corresponding author}

D. Gasperikova, DIABGENE Laboratory, Institute of Experimental Endocrinology, Slovak Academy of Sciences, Vlarska 3, SK-833 06
Bratislava, Slovakia. Fax: + 42125479 3472. E-mail: daniela.gasperikova@savba.sk

\section{Introduction}

Non-syndromic monogenic obesity is a result of a mutation in one of the genes encoding enzymes or receptors of the leptin-melanocortin pathway, which plays a key role in regulation of satiety and maintaining energy homeostasis in the body. The most common of them are loss of function mutations in the gene coding Melanocortin-4 receptor (MC4R) (Farooqi et al. 2003). MC4R in hypothalamus is activated by the hormone $\alpha$-MSH stimulating the downstream neurons for the production of hormones that evoke the feeling of satiety. Therefore, the loss of function $M C 4 R$ mutations leads in mutation carriers to an increased appetite in childhood. A typical phenotype of $M C 4 R$ mutations includes obesity onset in the early childhood due to the non-selective hyperphagia, acceleration in the linear growth, hyperinsulinemia, and normal blood pressure (Farooqi et al. 2003). Nevertheless, phenotype could vary also between individuals with the same mutation. Prevalence of $M C 4 R$ mutations is variable in different countries, i.e. $1.2-6.3 \%$ in obese children (these data are based on maximal frequency of $M C 4 R$ mutations published in each country) (Dubern et al. 2001, Nowacka-Woszuk et al. 2011). Data from Slovakia are lacking. Therefore, the aim 
of our study was 1) to search for MC4R mutations in obese children in Slovakia and compare their prevalence with other European countries, and 2) to describe the phenotype of the mutation carriers.

\section{Materials and Methods}

\section{Study design and participants}

Two hundred and sixty eight unrelated children and adolescents (140 males, and 128 females) of Caucasian ethnicity (born and living in Slovakia) aged from 2 to 18 years with body mass index above the $97^{\text {th }}$ percentile for age and sex, and obesity onset up to 11 years were recruited by pediatric endocrinologists throughout Slovakia over years 2009-2014. All patients with syndromic causes (e.g. Prader-Willi syndrome) of obesity were primarily excluded. Anthropometric data (i.e. height and weight) were taken by specialized nurses in pediatric endocrinology outpatient clinics. The body mass index percentiles and standard deviation score were calculated using International Obesity Task Force (IOTF) standards (Cole et al. 2000). The mean body mass index standard deviation score of the children and adolescents at the time of the DNA analysis was $3.1 \pm 0.8 \mathrm{SD}$, mean age at obesity onset $4.3 \pm 2.8$ years, and age at the time of examination was $10.5 \pm 4.4$ years. During regular health check-up, information on genetic testing was given and informed consent was signed. Clinical data about the disease character in the proband and family relatives and genealogic history were filled by the referring physician into the questionnaire. Samples of $8 \mathrm{ml}$ venous blood were collected into EDTA tubes (Sarstedt, Nümbrecht, Germany) for DNA analysis. A control population of randomly selected 45 unrelated lean subjects with $\mathrm{BMI}<25 \mathrm{~kg} / \mathrm{m}^{2}$ (mean 22.0 \pm 2.2 ) and no history of overweight or obesity during childhood or adolescence was also examined for mutations in $M C 4 R$. All control subjects were Caucasians, born and living in Slovakia.

\section{Molecular genetic analysis}

Genomic DNA was extracted from peripheral leukocytes using standard procedures, and the coding exons and intron/exon boundaries of the $M C 4 R$ gene were amplified by polymerase chain reaction (PCR) using previously described primers (Yeo et al. 2003). PCR products were sequenced using standard methods on an ABI/ /Hitachi 3500 resp. 3130 (Applied Biosystems, Warrington, UK) and were compared with the reference sequence NM_005912.2 using SeqScape software (version 2.1.1; Applied Biosystems, Warrington, UK). All identified variants were checked in the Database of Single Nucleotide Polymorphisms (http://www.ncbi.nlm.nih.gov/SNP/).

\section{Hormonal and other biochemical analyses}

Glucose, lipids, and insulin were measured from serum locally by standard laboratory protocols (Bratislava, Levice).

\section{Statistics}

All statistical analyses were performed using SPSS (version 17; SPSS, Chicago, IL, USA). The numeric parameters were evaluated as a mean \pm standard deviation. The comparison of prevalence was tested using the Mann-Whitney test. $\mathrm{P}$ values of $<0.05$ were considered as significant.

\section{Ethic Committee approval}

The present study was approved by the institutional Ethics Committees (University Hospital of Bratislava and National Institute of Endocrinology and Diabetology in Lubochna, Slovakia) and all of the participants or their parents (in case of individuals younger than 18 years) signed an informed consent for the genotype and phenotype analyses.

\section{Results}

MC4R genotypes of the obese children

In two obese probands out of $268(0.7 \%)$ two different previously described heterozygous MC4R mutations were identified (i.e. c.55delA/ p.Ser19Alafs*34/, c.380C $>$ T/p.Ser127Leu/) (Hainerova et al. 2007). The same heterozygous mutations were found also in the obese father (BMI $34.5 \mathrm{~kg} / \mathrm{m}^{2}$ ) of the proband with p.Ser19Alafs*34, and in the lean mother (BMI $24.2 \mathrm{~kg} / \mathrm{m}^{2}$ ) of the p.Ser127Leu mutation carriers (Fig. 1). Moreover, two previously described $M C 4 R$ polymorphisms were identified in heterozygous state (Hinney et al. 1999, Rosmond et al. 2001). The c.307G $>$ A (p. Val103Ile, rs2229616) variant was found in 8 probands, and c.751 A $>C$ (p. Ile251Leu, rs52820871) in further 2 probands.

\section{$M C 4 R$ genotypes of the lean controls}

No $M C 4 R$ mutation was found in the group of lean controls. Two previously described $M C 4 R$ polymorphisms, i.e. c.307G $>$ A (p.Val103Ile, rs2229616) 
and c.335C $>$ T (p.Thr112Met, rs13447329) were found in heterozygous state in one lean individual each.

\section{Phenotype of the MC4R mutation carriers}

Detailed phenotype characterizations of the probands with $M C 4 R$ mutation and cosegregation of the mutations with obesity in the families are displayed in the Table 1, and Figure 1, respectively. The nonsense mutation carrier had more severe phenotype and earlier obesity onset compared to the p.Ser127Leu mutation carrier (BMI standard deviation score 3.49 vs. 2.64, and 1 vs. 10 years of age at obesity onset) (Table 1). The p.Ser19Alafs*34 mutation was found also in the proband's father, who was obese as well (BMI $34.5 \mathrm{~kg} / \mathrm{m}^{2}$ ). We have found one lean p.Ser127Leu mutation carrier (proband's mother) without typical $M C 4 R$ phenotype.
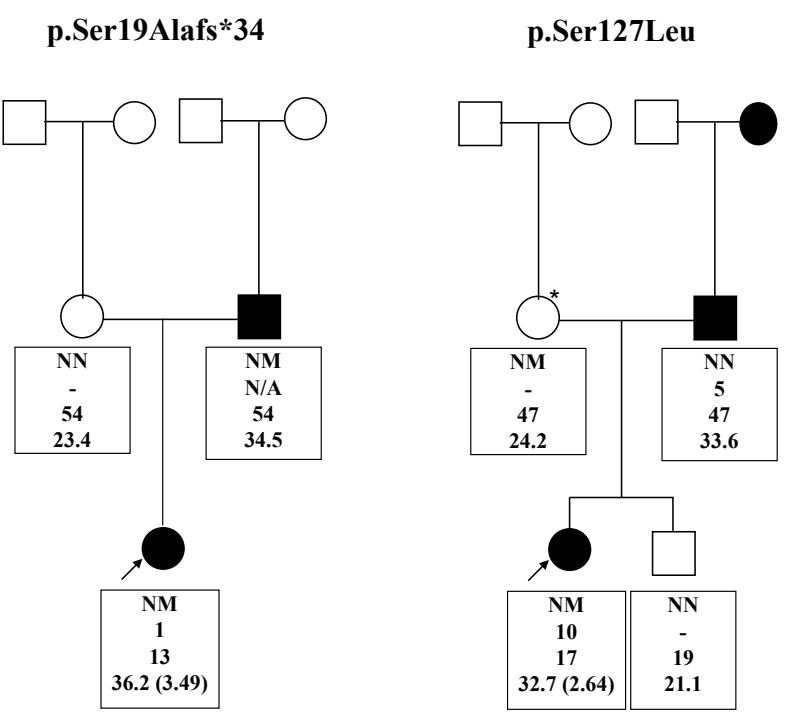

Fig. 1. Pedigrees of the families with $M C 4 R$ mutations. Squares represent male; circles represent female; open symbols are nonobese; and filled symbols are obese. Probands are indicated by an arrow. The lean mutation carrier (mother of the p.Ser127Leu proband) is indicated by $*$. The text below each individual represent: mutational status (NM - MC4R mutation positive; NN - wild type); age at diagnosis of obesity (- is for not applicable in lean persons), current age; BMI (in brackets BMI SDS). N/A is for not available.

\section{Discussion}

We have identified two different heterozygous MC4R mutations (i.e. p.Ser19Alafs*34, p.Ser127Leu) in two out of 268 obese children with the obesity onset below the age of 11 years. The prevalence of loss-offunction $M C 4 R$ mutations in obese children was 0.7 .
Table 1. Genetic, clinical and biochemical characteristics of the probands with MC4R mutations.

\begin{tabular}{|c|c|c|}
\hline Proband ID & MO56 & M0111 \\
\hline $\begin{array}{l}\text { Mutation nucleotide } \\
\text { level }\end{array}$ & c. $55 \mathrm{delA}$ & c. $380 \mathrm{C}>\mathrm{T}$ \\
\hline $\begin{array}{l}\text { Mutation-protein } \\
\text { level }\end{array}$ & p.Ser19Alafs*34 & p.Ser127Leu \\
\hline Reference & $\begin{array}{c}\text { (Buono et al. } \\
\text { 2005) }\end{array}$ & $\begin{array}{l}\text { (Lubrano- } \\
\text { Berthelier et } \\
\text { al. 2003) }\end{array}$ \\
\hline Age at obesity & & \\
\hline $\begin{array}{l}\text { onset/at investigation } \\
\text { (years) }\end{array}$ & $1 / 10$ & $10 / 16$ \\
\hline $\begin{array}{l}\text { BMI SDS at } \\
\text { investigation }\end{array}$ & 3.49 & 2.64 \\
\hline Height $(\mathrm{cm})$ & $\begin{array}{c}156 \\
\left(90^{\text {th }} \text { percentile }\right)\end{array}$ & $\begin{array}{c}174 \\
\left(90^{\text {th }} \text { percentile }\right)\end{array}$ \\
\hline $\begin{array}{l}\text { Blood pressure } \\
(\mathrm{mm} \mathrm{Hg})\end{array}$ & N/A & $125 / 70$ \\
\hline $\begin{array}{l}\text { Glucose 0/120 min } \\
\text { oGTT (mmol/l) }\end{array}$ & $5.2 / 4.5$ & $4.2 / 4.6$ \\
\hline $\begin{array}{l}\text { Insulin fasting/peak } \\
\text { during oGTT (mU/l) }\end{array}$ & $10.4 / \mathrm{NA}$ & $27.5 / 237.6$ \\
\hline $\begin{array}{l}\text { Total cholesterol } \\
\text { (mmol/l) }\end{array}$ & 4.6 & 3.9 \\
\hline $\begin{array}{l}\text { HDL cholesterol } \\
(\mathrm{mmol} / \mathrm{l})\end{array}$ & 1.0 & 1.2 \\
\hline $\begin{array}{l}\text { Triglycerides } \\
(\mathrm{mmol} / \mathrm{l})\end{array}$ & 2.2 & 1.2 \\
\hline $\begin{array}{l}\text { Adrenocorticotropic } \\
\text { hormone }(\mathrm{pg} / \mathrm{ml})\end{array}$ & 30.0 & 17.0 \\
\hline Cortisol & 301.0 & 447.8 \\
\hline $\begin{array}{l}\text { Thyroid-stimulating } \\
\text { hormone }(m U / l)\end{array}$ & 11.4 & 12.1 \\
\hline $\begin{array}{l}\text { Free thyroxine } \\
\text { (pmol/l) }\end{array}$ & 10.3 & 4.0 \\
\hline Other disorders & hypothyroidism & none \\
\hline Treatment & regime changes & regime changes \\
\hline
\end{tabular}

Nucleotide numbering according to reference sequence NM_005912.2 with the +1 position corresponding to the A of the major start codon.

\section{Strengths and limitations}

Strength of our study is a relatively high number of participants with respect to the number of inhabitants in Slovakia (5.4 million), and that all of the children were of one ethnicity (Caucasians, born and 
living in Slovakia). Strength is also the participation of several clinics from various parts of Slovakia. Limitation could be the low number of identified obese carriers what could influence the accuracy of frequency calculation, and also the lower number of individuals in the control group.

\section{$M C 4 R$ genotypes}

Both of the identified mutations were previously described (Hainerova et al. 2007). The missense mutation p.Ser127Leu is located on the third transmembrane domain of the MC4R gene (LubranoBerthelier et al. 2003). The functional study confirmed the reduced expression of the receptor on the surface of HEK 293 cells and Neuro 2A cells. This mutation was found several times in both obese and lean populations (Lubrano-Berthelier et al. 2003, Hainerova et al. 2007, Nowacka-Woszuk et al. 2011). This fact indicates that it may be one of the most prevalent $M C 4 R$ mutations in Europe (Valli-Jaakola et al. 2004, Hainerova et al. 2007, Santoro et al. 2009, Nowacka-Woszuk et al. 2011).

The p.Ser19Alafs*34 mutation results from a single nucleotide deletion in the codon 19 (c.55delA) shifting the reading frame for subsequent 33 amino acids before a premature stop codon is introduced at codon 52 (Buono et al. 2005). Thus, the truncated protein consists of 51 amino acids with only 18 original N-terminal amino acids and lacks all functional domains. This mutation was found in severely obese (Buono et al. 2005, Hainerova et al. 2007) as well as in few lean individuals (Hainerova et al. 2007). In our study this mutation co-segregated with the obesity phenotype in the family.

Finding a $M C 4 R$ mutation in a lean individual (in our study the mother of the proband carrying p.Ser127Leu mutation) was previously described in several studies (Hainerova et al. 2007). This phenomenon could be explained by involvement of other genetic or environmental factors influencing the BMI.

Prevalence of MC4R mutations among children in other studies

Compared to other studies from Europe, prevalence of $M C 4 R$ mutations among obese children in Slovakia was one of the lowest (Table 2). We focused on several issues with possible impact on the $M C 4 R$ prevalence, particularly age of obesity onset, BMI, and ethnic origin of the participants.

Age of obesity onset could dramatically influence the outcomes. For example, two studies from Belgium (Beckers et al. 2006, 2010) have found 0 and 6 MC4R mutations in 123 and 112 children, respectively. Both of the studies had similar inclusion criteria, the main difference was the mean age at DNA analysis (3 children plus 120 adolescents with mean age 16.8 years versus 71 children plus 41 adolescents with mean age 14.1 years) and lower mean age of the obesity onset in the latter study (based on the discussion section in Beckers et al. 2010, exact data not shown). This phenomenon is supported also by data from two Italian studies (Santoro et al. 2009), that have found a higher $M C 4 R$ prevalence in the study including children with lower age of obesity onset $(1.6 \%$ among children with obesity onset $2.8 \pm 2.0$ years versus $0.5 \%$ in children with obesity onset $4.5 \pm 2.6$ years) (Miraglia Del Giudice et al. 2002). According to a study by Stutzmann et al. (2008), age of obesity onset in $M C 4 R$ mutation carriers is decreasing - also in mentioned studies from Belgium and Italy the higher prevalence was achieved by decreasing the of age of obesity onset in the study group in both later studies, i.e. Beckers et al. (2010) and Santoro et al. (2009), respectively. Nevertheless, the Czech study with higher $M C 4 R$ mutations prevalence (Hainerova et al. 2007) had higher mean age at obesity onset than children and adolescents in our study.

Severity of obesity could also contribute to differences in prevalence of the $M C 4 R$ mutations in various studies, as two of three studies showing prevalence more than $5 \%$ included individuals with severe obesity only (Dubern et al. 2001, Farooqi et al. 2003). On the other hand, Beckers et al. (2010) included also individuals with overweight showing the prevalence of $5.4 \%$. Moreover, the Spanish study (Ochoa et al. 2007) has found higher prevalence of $M C 4 R$ mutations in the overweight group than in the obese subjects $(2.3 \%$ vs. $1.3 \%$ ).

Another issue could be the ethnic origin of the participating children. Countries with higher prevalence of the $M C 4 R$ mutations had ethnically more heterogeneous study populations (included children of non-European origin), compared to the countries with the lower one (i.e. Poland and Slovakia). This phenomenon was apparent in the Norwegian study, as the general prevalence was much higher than the prevalence in children of Norwegian origin only $(1.6 \%$ vs. $0.7 \%)$. On the other hand, in the Dutch study the MC4R mutations were more common among children of the Dutch ethnicity ( $3.5 \%$ vs. $2.1 \%$ ). 


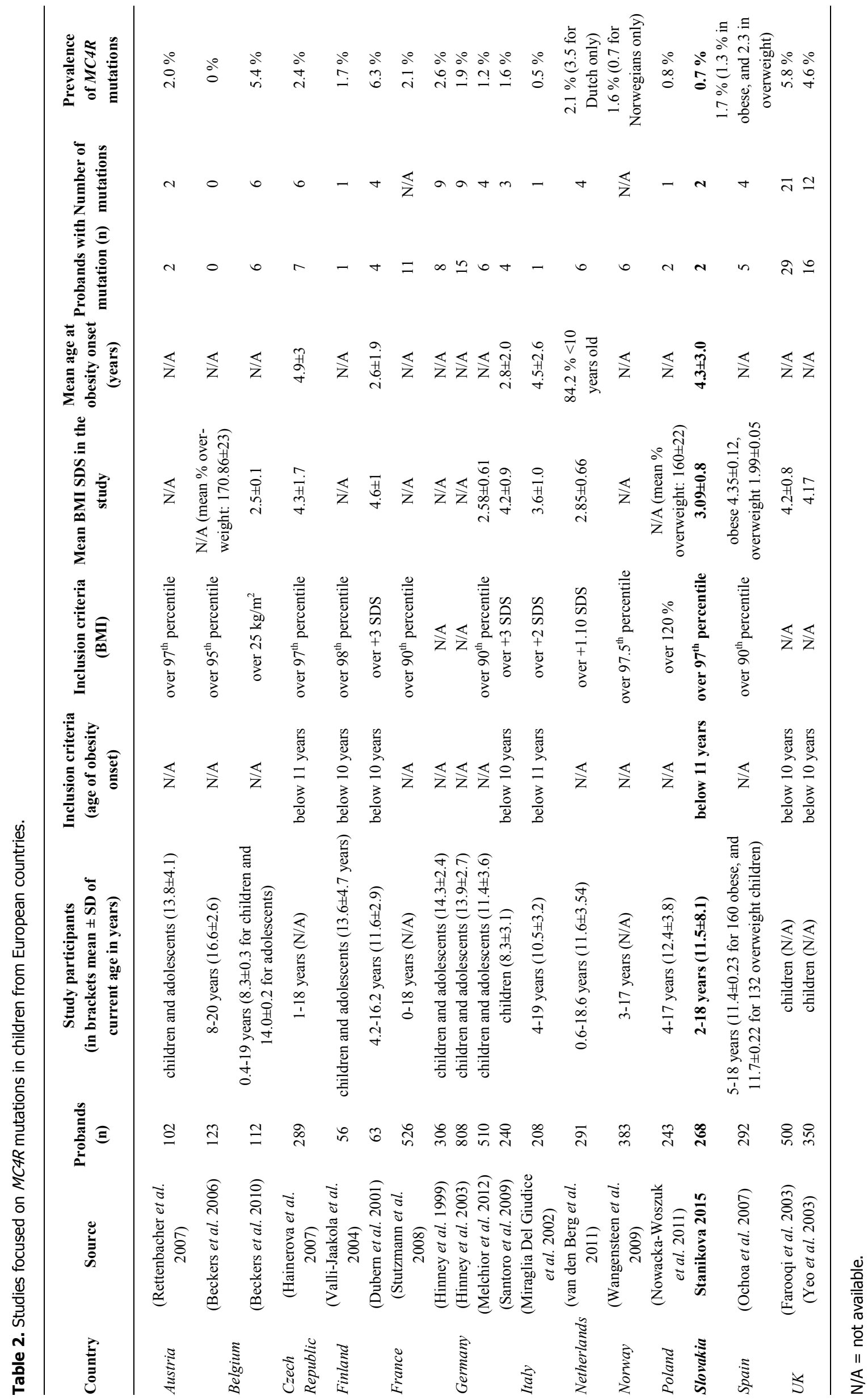


Prevalence of $M C 4 R$ mutations could be influenced also by variable penetrance, which seems not to correspond with the general prevalence of obesity (e.g. in a Greek study, the prevalence of $M C 4 R$ mutations was lower in obese group than in lean controls; Rouskas et al. 2012), despite of a relatively high general obesity prevalence - according to the http://www.worldobesity.org/ aboutobesity/world-map-obesity/). Nevertheless, in our study we did not find any $M C 4 R$ loss of function variants in the lean controls, only the lean mother of the p.Ser127Leu mutation carrier.

Small number of participants and a relatively low occurrence of $M C 4 R$ loss of function mutations may have also contributed to the differences of $M C 4 R$ prevalence, as only four studies until now had 500 or more participants (Farooqi et al. 2003, Hinney et al. 2003, Stutzmann et al. 2008, Melchior et al. 2012). Indeed, comparing to our data, only one study with $>200$ participants had significantly higher prevalence of $M C 4 R$ loss of function mutations (i.e. Farooqi et al. 2003, with $\mathrm{p}=0.001$ ).

We have considered also other potential factors but finding no or little impact on the prevalence of $M C 4 R$ mutations, i.e. highly-prevalent mutations with founder effect, or impact of the general prevalence of obesity in children and adults using the prevalence data published by the International Association for the Study of Obesity: http://www.iaso.org/resources/obesity-dataportal/resources/tables/ (but no significant correlation was found with $p>0.429$ for each issue).

\section{Conclusions}

Two of 268 obese children in Slovakia had two different MC4R mutations (p.Ser19Alafs*34, p.Ser127Leu). The proband with p.Ser127Leu mutation had a lean mother with the same mutation, pointing to nonpenetrance. The prevalence of loss of function $M C 4 R$ variants in Slovak obese children was $0.7 \%$, what is one of the lowest frequencies in obese children in Europe.

\section{Conflict of Interest}

There is no conflict of interest.

\section{Acknowledgements}

We would like to thank all of the attending pediatric endocrinologists of the patients in Slovakia (particularly to Medical Doctors Kyskova, Bobulova, Chlupisova, Mendelova, Milanova, Hudakova, Valachova). We are also grateful to Ivica Masindova, $\mathrm{PhD}$, to $\mathrm{PhD}$ student Dominika Balaziova, and technician Ms. Alica Mitkova for their technical expertise, and for administrative support being provided to us by Ms. Zuzana Strapata and Ms. Renata Dornhoferova. This work was supported by research grants of the DIABGENE Laboratory (Transendogen/26240220051) which is supported by the Research \& Development Operational Programme and funded by the ERDF and Scientific Grant Agency of the Ministry of Education, Science, Research and Sport of the Slovak Republic 2/0166/14.

\section{References}

BECKERS S, MERTENS I, PEETERS A, VAN GAAL L, VAN HUL W: Screening for melanocortin-4 receptor mutations in a cohort of Belgian morbidly obese adults and children. Int J Obes (Lond) 30: 221-225, 2006.

BECKERS S, ZEGERS D, DE FREITAS F, PEETERS AV, VERHULST SL, MASSA G, VAN GAAL LF, TIMMERMANS JP, DESAGER KN, VAN HUL W: Identification and functional characterization of novel mutations in the melanocortin-4 receptor. Obes Facts 3: 304-311, 2010.

BUONO P, PASANISI F, NARDELLI C, IENO L, CAPONE S, LIGUORI R, FINELLI C, ORIANI G, CONTALDO F, SACCHETTI L: Six novel mutations in the proopiomelanocortin and melanocortin receptor 4 genes in severely obese adults living in southern Italy. Clin Chem 51: 1358-1364, 2005.

COLE TJ, BELLIZZI MC, FLEGAL KM, DIETZ WH: Establishing a standard definition for child overweight and obesity worldwide: international survey. BMJ 320: 1240-1243, 2000.

DUBERN B, CLEMENT K, PELLOUX V, FROGUEL P, GIRARDET JP, GUY-GRAND B, TOUNIAN P: Mutational analysis of melanocortin-4 receptor, agouti-related protein, and alpha-melanocyte-stimulating hormone genes in severely obese children. J Pediatr 139: 204-209, 2001.

FAROOQI IS, KEOGH JM, YEO GS, LANK EJ, CHEETHAM T, O'RAHILLY S: Clinical spectrum of obesity and mutations in the melanocortin 4 receptor gene. $N$ Engl J Med 348: 1085-1095, 2003. 
HAINEROVA I, LARSEN LH, HOLST B, FINKOVA M, HAINER V, LEBL J, HANSEN T, PEDERSEN O: Melanocortin 4 receptor mutations in obese Czech children: studies of prevalence, phenotype development, weight reduction response, and functional analysis. J Clin Endocrinol Metab 92: 3689-3696, 2007.

HINNEY A, SCHMIDT A, NOTTEBOM K, HEIBULT O, BECKER I, ZIEGLER A, GERBER G, SINA M, GORG T, MAYER H, SIEGFRIED W, FICHTER M, REMSCHMIDT H, HEBEBRAND J: Several mutations in the melanocortin-4 receptor gene including a nonsense and a frameshift mutation associated with dominantly inherited obesity in humans. J Clin Endocrinol Metab 84: 1483-1486, 1999.

HINNEY A, HOHMANN S, GELLER F, VOGEL C, HESS C, WERMTER AK, BROKAMP B, GOLDSCHMIDT H, SIEGFRIED W, REMSCHMIDT H, SCHAFER H, GUDERMANN T, HEBEBRAND J: Melanocortin-4 receptor gene: case-control study and transmission disequilibrium test confirm that functionally relevant mutations are compatible with a major gene effect for extreme obesity. J Clin Endocrinol Metab 88: 42584267, 2003.

LUBRANO-BERTHELIER C, DURAND E, DUBERN B, SHAPIRO A, DAZIN P, WEILL J, FERRON C, FROGUEL P, VAISSE C: Intracellular retention is a common characteristic of childhood obesity-associated MC4R mutations. Hum Mol Genet 12: 145-153, 2003.

MELCHIOR C, SCHULZ A, WINDHOLZ J, KIESS W, SCHONEBERG T, KORNER A: Clinical and functional relevance of melanocortin-4 receptor variants in obese German children. Horm Res Paediatr 78: 237-246, 2012.

MIRAGLIA DEL GIUDICE E, CIRILLO G, NIGRO V, SANTORO N, D'URSO L, RAIMONDO P, COZZOLINO D, SCAFATO D, PERRONE L: Low frequency of melanocortin-4 receptor (MC4R) mutations in a Mediterranean population with early-onset obesity. Int J Obes Relat Metab Disord 26: 647-651, 2002.

NOWACKA-WOSZUK J, CIESLAK J, SKOWRONSKA B, MAJEWSKA KA, STANKIEWICZ W, FICHNA P, SWITONSKI M: Missense mutations and polymorphisms of the MC4R gene in Polish obese children and adolescents in relation to the relative body mass index. J Appl Genet 52: 319-323, 2011.

OCHOA MC, AZCONA C, BIEBERMANN H, BRUMM H, RAZQUIN C, WERMTER AK, MARTINEZ JA, HEBEBRAND J, HINNEY A, MORENO-ALIAGA MJ, MARTI A, PATINO A, CHUECA M, OYARZABAL M, PELACH R: A novel mutation Thr162Arg of the melanocortin 4 receptor gene in a Spanish children and adolescent population. Clin Endocrinol (Oxf) 66: 652-658, 2007.

ROSMOND R, CHAGNON M, BOUCHARD C, BJORNTORP P: A missense mutation in the human melanocortin-4 receptor gene in relation to abdominal obesity and salivary cortisol. Diabetologia 44: 1335-1338, 2001.

ROUSKAS K, MEYRE D, STUTZMANN F, PALETAS K, PAPAZOGLOU D, VATIN V, MARCHAND M, KOUVATSI A, FROGUEL P: Loss-of-function mutations in MC4R are very rare in the Greek severely obese adult population. Obesity (Silver Spring) 20: 2278-2282, 2012.

SANTORO N, CIRILLO G, XIANG Z, TANAS R, GREGGIO N, MORINO G, IUGHETTI L, VOTTERO A, SALVATONI A, Di PIETRO M, BALSAMO A, CRINO A, GRANDONE A, HASKELL-LUEVANO C, PERRONE L, DEL GIUDICE EM: Prevalence of pathogenetic MC4R mutations in Italian children with early onset obesity, tall stature and familial history of obesity. BMC Med Genet 10: 25, 2009.

STUTZMANN F, TAN K, VATIN V, DINA C, JOURET B, TICHET J, BALKAU B, POTOCZNA N, HORBER F, O'RAHILLY S, FAROOQI IS, FROGUEL P, MEYRE D: Prevalence of melanocortin-4 receptor deficiency in Europeans and their age-dependent penetrance in multigenerational pedigrees. Diabetes 57: 2511-2518, 2008.

VALLI-JAAKOLA K, LIPSANEN-NYMAN M, OKSANEN L, HOLLENBERG AN, KONTULA K, BJORBAEK C, SCHALIN-JANTTI C: Identification and characterization of melanocortin-4 receptor gene mutations in morbidly obese finnish children and adults. J Clin Endocrinol Metab 89: 940-945, 2004.

VAN DEN BERG L, VAN BEEKUM O, HEUTINK P, FELIUS BA, VAN DE HEIJNING MP, STRIJBIS S, VAN SPAENDONK R, PIANCATELLI D, GARNER KM, EL AOUAD R, SISTERMANS E, ADAN RA, DELEMARRE-VAN DE WAAL HA: Melanocortin-4 receptor gene mutations in a Dutch cohort of obese children. Obesity (Silver Spring) 19: 604-611, 2011. 
YEO GS, LANK EJ, FAROOQI IS, KEOGH J, CHALLIS BG, O'RAHILLY S: Mutations in the human melanocortin4 receptor gene associated with severe familial obesity disrupts receptor function through multiple molecular mechanisms. Hum Mol Genet 12: 561-574, 2003. 